Expert Systems - A Practical Introduction 


\section{Macmillan Computer Science Series}

\section{Consulting Editor}

Professor F. H. Sumner, University of Manchester

S. T. Allworth, Introduction to Real-time Software Design

Ian O. Angell, A Practical Introduction to Computer Graphics

R. E. Berry and B. A. E. Meekings, $A$ Book on $C$

G. M. Birtwistle, Discrete Event Modelling on Simula

T. B. Boffey, Graph Theory in Operations Research

Richard Bornat, Understanding and Writing Compilers

J. K. Buckle, The ICL 2900 Series

J. K. Buckle, Software Configuration Management

J. C. Cluley, Interfacing to Microprocessors

Robert Cole, Computer Communications

Derek Coleman, A Structured Programming Approach to Data

Andrew J. T. Colin, Fundamentals of Computer Science

Andrew J. T. Colin, Programming and Problem-solving in Algol 68

S. M. Deen, Principles and Practice of Database Systems

P. M. Dew and K. R. James, Introduction to Numerical Computation in Pascal

M. R. M. Dunsmuir and G. J. Davies, Programming the UNIX System

K. C. E. Gee, Introduction to Local Area Computer Networks

J. B. Gosling, Design of Arithmetic Units for Digital Computers

Roger Hutty, Fortran for Students

Roger Hutty, Z80 Assembly Language Programming for Students

Roland N. Ibbett, The Architecture of High Performance Computers

P. Jaulent, The 68000 - Hardware and Software

M. J. King and J. P. Pardoe, Program Design Using JSP - A Practical Introduction

H. Kopetz, Software Reliability

E. V. Krishnamurthy, Introductory Theory of Computer Science Graham Lee, From Hardware to Software: an introduction to computers

A. M. Lister, Fundamentals of Operating Systems, third edition

G. P. McKeown and V. J. Rayward-Smith, Mathematics for Computing

Brian Meek, Fortran, PL/1 and the Algols

Derrick Morris, An Introduction to System Programming - Based on the PDP11

Derrick Morris and Roland N. Ibbett, The MU5 Computer System

C. Queinnec, LISP

John Race, Case Studies in Systems Analysis

W. P. Salman, O. Tisserand and B. Toulout, FORTH

L. E. Scales, Introduction to Non-Linear Optimization

P. S. Sell, Expert Systems - A Practical Introduction

Colin J. Theaker and Graham R. Brookes, A Practical Course on Operating Systems

M. J. Usher, Information Theory for Information Technologists

B. S. Walker, Understanding Microprocessors

Peter J. L. Wallis, Portable Programming

I. R. Wilson and A. M. Addyman, A Practical Introduction to Pascal - with BS 6192, second edition 


\title{
Expert Systems \\ A Practical Introduction
}

\author{
Peter S. Sell
}

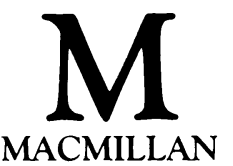


All rights reserved. No reproduction, copy or transmission of this publication may be made without written permission.

No paragraph of this publication may be reproduced, copied or transmitted save with written permission or in accordance with the provisions of the Copyright Act 1956 (as amended).

Any person who does any unauthorised act in relation to this publication may be liable to criminal prosecution and civil claims for damages.

First published 1985

Published by

Higher and Further Education Division

MACMILLAN PUBLISHERS LTD

Houndmills, Basingstoke, Hampshire RG21 2XS

and London

Companies and representatives

throughout the world

British Library Cataloguing in Publication Data

Sell, Peter S.

Expert systems: a practical introduction.

1. Expert systems (Computer science)

I. Title

001.64 QA76.9.E96

ISBN 978-1-349-07418-1 ISBN 978-1-349-07416-7 (eBook)

DOI 10.1007/978-1-349-07416-7 


\section{Contents}

Preface

vii

1 origins 1

1.1 Artificial Intelligence 1

1.2 Problem solving 3

Questions 6

Further reading 6

2 Examples 7

2.1 DENDRAL 7

2.2 MYCIN 8

2.3 PROSPECTOR 9

$\begin{array}{ll}2.4 \mathrm{RI} & 10\end{array}$

2.5 Summary 11

Further reading 11

3 Characteristics 13

3.1 Essential characteristics 13

3.2 Desirable characteristics $\quad 15$

3.3 Classification 18

Questions 20

4 Creation 21

4.1 How expert systems are built 21

4.2 Knowledge acquisition $\quad 26$

4.3 Knowledge representation 31

4.4 Internal representation and the compiler 35

$\begin{array}{ll}\text { Further reading } & 36\end{array}$

5 Operation 38

5.1 The basics 38

5.2 Forward chainer 40

5.3 The basic backward chainer 45

5.4 Improvements 51

5.5 Summary 60

Further reading 61 
6 Validation $\quad 62$

6.1 Why validate? $\quad 62$

6.2 What to validate? 64

$\begin{array}{ll}\text { Further reading } & 75\end{array}$

7 Facilities $\quad 76$

$\begin{array}{ll}7.1 \text { Questions } & 76\end{array}$

$\begin{array}{ll}7.2 \text { Explanations } & 77\end{array}$

7.3 Uncertainty $\quad 86$

7.4 Summary. 90

Further reading $\quad 90$

8 Practice $\quad 92$

$\begin{array}{ll}\text { Epilogue } & 95\end{array}$

$\begin{array}{ll}\text { References } & 96\end{array}$

$\begin{array}{lr}\text { Index } & 98\end{array}$ 


\section{Preface}

Expert systems represent a new opportunity in computing. They open up avenues of application so far closed and allow new problems to be tackled. Although the ideas underpinning the technique are still in ferment, the techniques they employ have been in use for two decades or more. Nevertheless, it was only recently that they achieved prominence in the public eye and started to be exploited by commerce and industry. One result of their neglect is that practical information on the subject is hard to come by and, as is often the case with a little-known territory, the subject appears more mysterious and forbidding than its nature warrants. It is true that, in the large area that expert systems span, complex and powerful techniques can be found at work. Nevertheless, the theme of this book is that in at least one mode of use, namely that of the so called 'single shot' advisory systems, the appropriate techniques used to give form to such systems lie close to the mainstream of software engineering. What is undoubtedly difficult and new is how to give them content, how to imbue them with knowledge. The situation will remain thus until generally applicable methods of knowledge acquisition are found.

This book is aimed at the advanced undergraduate or new practitioner. I have assumed that he (by which term I mean here and all through the book 'he or she') is a competent programmer who is familiar with the software development life cycle, at home with basic data structures, and conversant enough with high-level languages not to baulk at notation that is eclectic but whose meaning, I hope, is self-evident. I also assume that he has at least a nodding acquaintance with compilers and what they can do. The book is meant to give the reader sufficient insight and practical guidance to enable him to construct an expert system 
shell using his favourite programming language. To allow the latter, I have refrained from using some powerful facilities - such as 'eval' - which could simplify the algorithms but could create problems in implementation if not provided by the host language.

The first three chapters introduce the topic through an overview of Artificial Intelligence, a brief history and characterisation of expert systems. Chapter 4 addresses the question of how to develop and maintain these systems. Chapters 5 and 7 tackle the technical issues. They concentrate on problems unique to the field and touch lightly on matters that the reader may already be familiar with or can obtain information on from other, specialist sources. The last chapter gives some help with assessing new applications. In my experience, there is never a shortage of ideas for using expert systems, so what is needed is not a catalogue of possibilities but advice on how to assess them. There are a few questions to test the reader's understanding and, where there is material for further reading, I give references after each chapter. An aggregate list of these is given at the end of the book. I have limited references to those available to the general public.

I am, of course, responsible for the words and ideas but, like any author, I owe indebtedness to many others - too many to name them all. I would like to express my appreciation to members of the Knowledge Engineering Group of SPL for their help, to my superiors and colleagues for their encouragement, to sPL-Insight for acting as a sounding board, but most of all to my wife, Frances, for correcting my more egregious errors and for continuing to treat with love and patience her husband turned lodger.

Finally, because so much is still in the melting pot, this book can hope to be no more than a snapshot of what we know today. I hope, nevertheless, that it will help those who wish to get their feet wet, and provide for others at least a clearly focused target for refutation and growth. 